\title{
Ezio Flavio Bazzo - Inventário de cretinices: ou o prazer de jogar pérolas aos porcos
}

Brasília: Siglaviva, 2014

\section{Erivelto da Rocha Carvalho ${ }^{1}$}

Seria o Inventário de cretinices ou o prazer de jogar pérolas aos porcos de Ezio Flavio Bazzo um estranho exemplo de obra publicada por um exmaldito? O que significaria isso, a "literatura de ex-malditos"? É possível tentar enquadrar esse tipo de texto em alguma cômoda tipologia usada pelas histórias literárias tradicionais?

Essas são perguntas que poderão assaltar o leitor quando encontrar em alguma prateleira o último livro publicado por Bazzo numa cuidada edição da brasiliense Siglaviva, editora surgida há poucos anos e que vem divulgando obras de autores que estão longe do grande mercado editorial do país, tanto geograficamente falando quanto no que diz respeito a outros critérios.

É importante remeter inicialmente ao contexto de publicação de Bazzo para tratar de seu último livro, pois, para os que durante os anos 1980 e 1990 cresceram vendo suas festivas e orgulhosas autopublicações, é inevitável não se perguntar onde foi parar a radicalidade daqueles anos, quando se pensa numa trajetória forjada à margem dos esquemas de circulação e divulgação da obra literária.

Basta navegar pelo melancólico oráculo da modernidade para surpreender-se ao saber que Bazzo agora não só escreve um blog, como também que alguns de seus títulos anteriores foram reeditados por outra editora de Brasília, o que leva a pensar se não estaria em curso uma mudança no mundo da publicação brasileira, uma metamorfose que esteja fazendo com que livros que poderiam ser tidos até certo tempo como "perigosos" possam agora estar sendo considerados como o que são, ou seja, como simples expressão de um ponto de vista que pode agradar ou enfurecer leitores, críticos e editores.

A mais recente obra de Bazzo configura-se mais uma vez a partir de um texto incômodo, carregado de ironia cínica que se deixa ver através

\footnotetext{
${ }^{1}$ Professor de literatura espanhola e hispano-americana da Universidade de Brasília (UnB), Brasília, DF, Brasil. E-mail: eriveltocarvalho@hotmail.com.
} 
do humor ácido presente em várias de suas melhores páginas, entre elas as de outras obras que poderiam se ligar ao seu atual inventário, tal como Maldições, prazeres e verdades (1987, tradução em português de Más allá de la comedia cotidiana) e/ ou a Arte de cuspir ou a dialética dos porcos (1994).

Desta última, Bazzo observa o aforismo de que a maldição lançada aos céus sempre se volta contra o próprio blasfemador. Sendo assim, o Inventário de cretinices não deixa de ser também uma espécie de acerto de contas que o personagem do narrador-autor faz com sua radical opção por escrever sempre livremente e à margem de tudo, sem levar em consideração os possíveis reparos dos seus leitores e críticos, numa espécie de insolência contínua, altiva e descarada.

Os livros de Ezio Flavio Bazzo transitam assim por uma fluida fronteira entre a psicologia, a filosofia, a política e a literatura, e o último não é diferente. No entanto, chama atenção neste o peso que a dimensão narrativa da obra toma a despeito do afã de polêmica que o autor cultivou e cultiva desde sempre. Estruturado como um diário de viagens dividido em 10 capítulos ou fragmentos, o Inventário de cretinices toma o pretexto do deslocamento, entendido não só em seu aspecto físico ou geográfico, para sustentar uma série de digressões contra os discursos e poderes constituídos, entre os quais se encontram o capital, o Estado, a Igreja e as religiões (a arte tomada como uma delas) e aí por diante.

Mas, apesar da estrutura formal de diário, o livro de Bazzo se define fundamentalmente como um breve tratado sobre a pequenez e a miséria do destino humano na Terra, esta tomada como uma espécie de poço sem fundo, abismo por onde transita a humanidade e o próprio autor (retomando a ideia inicial e que encerra a série de digressões).

Também se destaca a dimensão memorialística da obra, ao constituirse em vários pontos como comentários pessoais, biográficos só na medida em que o discurso forjado pelo narrador no diário pouco se distancia do relato em primeira pessoa, a não ser nos momentos em que são indicadas uma série de situações que se desprendem de suas andanças por Marselha, que formam a maior parte dos capítulos do livro.

Aqui vale um parêntesis para chamar a atenção dessa obra no conjunto da produção de Ezio Flavio Bazzo, pois há uma opção no Inventário de cretinices por refletir também sobre a condição de uma filosofia nova num mundo caduco, ou sobre a situação de um velho anarquismo iconoclasta diante da mais nova crise que movimenta o capitalismo mundial. Essa relação entre o novo e o jovem amplia em 
outro sentido a crítica voraz que se dá no plano da relação entre o pequeno e o grande visto através do nanismo como metáfora.

"Nada é puro! Tudo está mesclado!" (Bazzo, 2014, p.118). A frase poderia ser a consigna dessa narrativa híbrida, misto de ensaio filosófico e diário de passagem que toma a figura do anão como "arquétipo" ou "matriz" simbólica da pequenez dos grandes, ou metáfora central de uma dialética ou dinâmica que leva à confrontação entre o nanismo econômico-cultural do capitalismo decadente com a mania de grandeza dos gigantes de plantão, sejam eles de que tipo for.

O diário é escrito fundamentalmente a partir de Marselha, mas retoma memórias de vida e de outras viagens do narrador, sua passagem antes de chegar à França por um Portugal decadente, mais especificamente pela cidade do Porto, e lembranças motivadas por notas de viagem à China, viagens anteriores que servem para dar o pontapé às digressões estritamente marselhesas do livro.

O primeiro e o segundo capítulo, o capítulo português e o chinês da obra, apresentam-se como fundamentais na medida em que o primeiro se constitui como uma espécie de Ecce Homo inspirado na busca do viajante pelas obras de Albino Forjaz de Sampaio (1889-1949) num sebo português, e o segundo passa do plano mais geral e introdutório de crítica à mesquinhez para transformar-se num radical comentário sobre o despedaçamento das ilusões humanas a partir da própria imagem do corpo, corpo social e sexual comentado numa sequência de passagens de caráter caricatural e grotesco, com reflexões sobre os impulsos animalescos que ilustram e dominam a vida cotidiana.

Uma dimensão da edição do Inventário de cretinices que não pode ser esquecida é o da relação entre o texto de Bazzo e a trintena de imagens que ilustram o livro, que de certa forma exercem uma função semelhante ao da bibliografia que aparece ao final da publicação, fundamentando o projeto maior de dessacralização e desorganização de qualquer ideia de cânone literário, pois entre os intentos iconoclastas desse inventário sui generis se encontra o desejo de pôr abaixo a noção da "grande" literatura, optando conscientemente por marginais, breves, jovens e cegos de vários tipos.

Por fim, apesar das várias passagens em que o autor destaca as figuras tutelares de Albino Forjaz de Sampaio e Fialho de Almeida, tidos como guias dos seus passeios por Marselha, a "capital do crime", é difícil não notar que a emergência de um Bazzo mais preocupado com a subversão 
do cânone literário (inclusive no que diz respeito à literatura de viagens, esse gênero suspeito) parece dever muito mais a sua aproximação a Jorge Luis Borges (citado várias vezes, mas não incluído na bibliografia maldita final que completa o volume) dos relatos de Ficciones ou da Historia universal de la infamia, poeta do Olvido e modelo maior de certo anarquismo epistêmico que se projeta através da literatura.

Se Bazzo será visto como um maldito ou ex-maldito pelas próximas gerações de leitores, e pela história literária, só o tempo e os próprios leitores poderão dizer. De qualquer forma, esse raro livro fica marcado em sua produção como obra que retoma e estende o seu ânimo de enfrentar-se as normas e etiquetas convencionais que conduzem tanto a crítica quanto o mercado literário brasileiros.

\section{Referências}

BAZZO, Ezio Flavio (1994). A arte de cuspir ou a dialética dos porcos. Brasília: Lilith.

BAZZO, Ezio Flavio (2014). Inventário de cretinices: ou o prazer de jogar pérolas aos porcos. Barsília: Siglaviva.

BAZZO, Ezio Flavio (1987). Maldições, prazeres e verdades. Brasília: Lilith. 